\begin{tabular}{|c|c|}
\hline $\begin{array}{r}\text { ARTICLES } \\
\text { ARTÍ́CULOS }\end{array}$ & $\begin{array}{l}\text { GATEKEEPING, } \\
\text { GATEWATCHING, } \\
\text { REAL-TIME FEEDBACK: } \\
\text { New challenges for Journalism' }\end{array}$ \\
\hline $\begin{array}{r}\text { Copyright } \odot 2014 \\
\text { SBPjor / Associação } \\
\text { Brasileira de } \\
\text { Pesquisadores em } \\
\text { Jornalismo }\end{array}$ & $\begin{array}{l}\text { AXEL BRUNS } \\
\text { Queensland University of Technology, Australia }\end{array}$ \\
\hline
\end{tabular}

\begin{abstract}
How bloggers and other independent online commentators criticise, correct, and otherwise challenge conventional journalism has been known for years, but has yet to be fully accepted by journalists; hostilities between the media establishment and the new generation of citizen journalists continue to flare up from time to time. The old gatekeeping monopoly of the mass media has been challenged by the new practice of gatewatching: by individual bloggers and by communities of commentators which may not report the news first-hand, but curate and evaluate the news and other information provided by official sources, and thus provide an important service. And this now takes place ever more rapidly, almost in real time: using the latest social networks, which disseminate, share, comment, question, and debunk news reports within minutes, and using additional platforms that enable fast and effective ad hoc collaboration between users. When hundreds of volunteers can prove within a few days that a German minister has been guilty of serious plagiarism, when the world first learns of earthquakes and tsunamis via Twitter - how does journalism manage to keep up?
\end{abstract}

Keywords: Journalism. Citizen journalism. Gatewatching. Social media. Produsage.

\title{
GATEKEEPING, GATEWATCHING, REAL-TIME FEEDBACK: new challenges for Journalism
}

RESUMO - Faz vários anos que se sabe como os blogueiros e outros comentaristas online independentes criticam, corrigem e de outra maneira desafiam o jornalismo convencional, porém isso ainda não foi plenamente aceito pelos jornalistas; as hostilidades entre as empresas de mídia e a nova geração de jornalistas cidadãos continuam a irromper de vez em quando. $\mathrm{O}$ antigo monopólio de gatekeeping mantido pela mídia de massa tem sido desafiado pela nova prática de gatewatching: feita pelos blogueiros individuais e pelas comunidades de comentaristas que podem não fazer reportagem das notícias de primeira mão, porém fazem a curadoria e avaliam as notícias e outras informações fornecidas pelas fontes oficiais, e assim prestam um serviço importante. E isso ocorre atualmente com cada vez mais rapidez, quase em tempo real: usando as redes sociais mais recentes, que divulgam, compartilham, comentam, questionam e desacreditam as matérias noticiosas dentro de minutos, e usando plataformas adicionais que possibilitam a colaboração ad hoc rápida e eficaz entre os usuários. Quando centenas de voluntários podem provar dentro de alguns poucos dias que um ministro alemão foi culpado de plágio sério, quando o mundo inteiro fica sabendo de terremotos e tsunamis pelo Twitter - como é que o jornalismo consegue acompanhar tudo isso?

Palavras-chave: Jornalismo. Jornalismo cidadão. Gatewatching. Mídia social. Produsage. 


\title{
GATEKEEPING, GATEWATCHING, REALIMENTACIÓN EN TIEMPO REAL: nuevos desafíos para el periodismo
}

\begin{abstract}
RESUMEN - Hace ya varios años que los blogueros y otros comentaristas independientes en línea critican, corrigen $y$, en cierta forma, desafían al periodismo convencional. Sin embargo, esto aún no ha sido aceptado plenamente por los periodistas; las hostilidades entre las empresas de comunicación y la nueva generación de periodistas ciudadanos continúan irrumpiendo de tiempo en tiempo. El antiguo monopolio de gatekeeping mantenido por los medios de comunicación de masas ha sido desafiado por la nueva práctica del gatewatching: es realizada por blogueros individuales y por comunidades de comentaristas que pueden no hacer reportajes de noticias de primera mano, pero hacen la curaduría y evalúan las noticias y otras informaciones proporcionadas por las fuentes oficiales, prestando así un importante servicio. Y esto ocurre actualmente cada vez con más rapidez, casi en tiempo real, ya que utilizan las redes sociales más recientes, que divulgan, comparten, comentan, cuestionan y desacreditan los temas noticiosos en cuestión de minutos, y usan plataformas adicionales que posibilitan la colaboración ad hoc rápida y eficaz entre los usuarios. Cuando centenas de voluntarios pueden probar en unos pocos días que un ministro alemán es culpable de un plagio serio, cuando el mundo se entera de terremotos y tsunamis por Twitter, ¿cómo puede el periodismo acompañar todo esto? Palabras clave: Periodismo. Periodismo ciudadano. Gatewatching. Medios de comunicación sociales. Produsage.
\end{abstract}

\section{INTRODUCTION}

June 2009: faced with an overwhelming wealth of documents detailing British MPs' expenses claims, The Guardian resorts to extraordinary measures - it places its entire database of nearly half a million expenses documents online, and invites its readers to drive the investigative process. The project is a success: within the first 80 hours, a good third of all documents are reviewed at least superficially by Guardian readers, and more than 50 percent of all visitors to the site contribute actively to the reviewing process (ANDERSEN, 2009).

Projects such as this draw directly on the participative Web (VICKERY \& WUNSCH-VINCENT, 2007) practices summarised under the 'Web 2.0' label, of course. The Guardian's MPs' Expenses platform invited its users to directly participate in an experience of crowdsourced investigative journalism that was at once playful and meaningful: it provided a sense of adventure and competition by offering its participants an insight into the hitherto obscure world of parliamentary expenses claims, by hinting at the chance of discovering new information from the ludicrous (thousands of pounds spent on a new bird bath) to the criminal (double billing and phantom expenses), by enabling users to focus on their local MPs or on those they especially suspected of 
dishonest practices, and by providing instant progress scores designed

to encourage further participation. Speaking to the Nieman Journalism Lab, the developer of the platform highlighted especially these aspects of playfulness and instant gratification: "make it fun" and "launch immediately" (ANDERSEN, 2009).

A major initiative by a leading international news organisation, the MPs' Expenses platform and other projects like it mark a new phase in the evolving relationship between journalists and their audiences. They herald the slow death of top-down models of journalistic news coverage and information dissemination, and even of the gatekeeping model itself, and highlight instead the shift towards a more equal, if at times wary, collaborative engagement between journalism professionals and news users. This is a shift which has been a long time in the making: models for harnessing the collaborative participation of news audiences have existed at least since the late 1990s, or can be said to date back even further if the more limited attempts at 'public' or 'civic' journalism of the late 80 s and early 90 s are also to be included in this trajectory (see e.g. BLACK, 1997; GANS, 2003). Today, finally, the transition has been further sped up by the widespread availability of near real-time social media platforms which accelerate the news cycle even beyond the already significant pressures of 24-hour news channels. The result is the final breakdown of traditional journalistic gatekeeping models, and a corresponding shift towards gatewatching.

\section{FROM GATEKEEPING TO GATEWATCHING}

Gatekeeping in its classic form was a product of the frameworks for news production, distribution, and consumption as they existed during the heyday of the mass media age. Put simply, gatekeeping practices were simply a practical necessity: printed newspapers and the news bulletins of radio and television broadcasting could never offer more than a tightly edited selection of the day's news; judgments of which stories were most important for audiences to learn about (that is, which stories could be squeezed into the available newshole - the total space for news content available in the publication or broadcast) had to be made. Such decisions were especially critical, in fact, at a time when the total number of news publications in a given regional or national media sphere - the aggregate newshole available to the journalism industry - was also strictly limited: when only a handful of newspapers or broadcast news bulletins serviced the interested 
audience. Channel scarcity not only justifies gatekeeping practices themselves, but also demands particular scrutiny of these practices: the power and influence of editors over the news agenda is inversely proportional to the number of available news channels.

Such gatekeeping processes can be distinguished at three different stages of the journalistic process: input, output, and response (BRUNS, 2005). At the input stage, journalists themselves pre-select those news stories which they believe to be worthy of investigation and coverage - that is, which they assume have a reasonable chance of being selected for publication once the articles are written or the TV reports produced. At the output stage, editors select from the total amount of material generated by journalists and reporters only those stories which they deem to be of greatest importance to their audiences, which suit the available space within papers and bulletins, and which fit the general news areas expected to be covered by the publication (politics, economy, sports, human interest, ...). At the response stage, finally, a small selection of audience responses are chosen for inclusion in the following day's paper or for on-air broadcast - if a space for such audience responses is provided at all. Overall, then, the newshole is almost entirely closed to direct audience participation and contribution, and journalists and editors maintain total control: interests and reactions of news audiences are implied and assumed by journalists and editors who believe they have a 'feel' for what their readers, listeners, and viewers want, but rarely actively sought or tested by the journalism industry, beyond mere token gestures (readers' polls, vox-pop statements) or commercial market research.

Indeed, even attempts at 'public' or 'civic' journalism as they were popular in the 1980s and 1990s hardly change the situation: here, news organisations may pursue audience engagement initiatives aimed at "developing a means of letting those who make up that market finally see how the sausage is made - how we do our work and what informs our decisions", as Kovach \& Rosenstiel have described it (2001, p. 192), but this fails to significantly alter the power relations between journalists as news producers and audiences as news consumers (or indeed, a mere 'market'): notably, the choices of gatekeeping remain 'our work' and 'our decisions', even in this description, and audiences are only afforded a somewhat more detailed glimpse at how those processes take place. Such 'public' journalism amounts not to a conversation with the public, but merely to a show-and-tell exercise for the public: an ultimately somewhat patronising attempt to show the public how journalism works. 
Fundamentally, such 'public' journalism does nothing to change core journalistic practices, as Gans (2003, p. 98-9) notes: it "is unlikely to go beyond the ideological margins of conventional journalism. In contrast, I see participatory journalism as more citizen oriented, taking a political, and when necessary, adversarial, view of the citizen-official relationship." Indeed, for the most part such truly participatory (rather than merely 'public') journalism has arrived over the past decade and more not from within the conventional journalism industry, but from outside it. This shift has been driven by two aspects which have combined to replace gatekeeping with gatewatching practices: the continuing multiplication of available channels for news publication and dissemination, especially since the emergence of the World Wide Web as a popular medium, and the development of collaborative models for user participation and content creation which are now often summarised under the 'Web 2.0' label.

First, as gatekeeping is a practice that is fundamentally born out of an environment of scarcity (of news channels, and of newshole space within those channels), any growth in the overall newshole must necessarily challenge its role. To begin with, if more print news publications and more broadcast channels covering the news become available, why must all of them adhere to nearly identical conventions of what is and is not newsworthy, for example? And further, especially as news publications establish themselves in online environments, where available page counts or broadcast lengths no longer inherently limit the depth, breadth, and length of journalistic coverage, why should a strict regime of gatekeeping still be necessary at all? A need for editorial intervention to direct potential news audiences to what are deemed to be the most important stories still remains, perhaps, but this need can now be addressed not by excluding all those news stories which fall below a certain threshold of importance set by the editor, as is practiced through gatekeeping, but simply by especially highlighting from the now massively enlarged newshole those stories which are seen to be most important. Indeed, this shift from excluding the less important to highlighting the more important is not just a possibility, but a necessity, as Bardoel and Deuze have pointed out:

with the explosive increase of information on a worldwide scale, the necessity of offering information about information has become a crucial addition to journalism's skills and tasks [...]. This redefines the journalist's role as an annotational or orientational one, a shift from the watchdog to the "guidedog" (Bardoel; Deuze, 2001, p. 94). 
Second, online media in particular have made it possible for audiences - or more precisely, users - to skip past news publications to directly connect with the organisations, institutions, and individuals in which they are interested - to follow first-hand the press releases and public statements of governments, politicians, companies, NCOs, and other figures of public life. Additionally, such active users are now also able to share with others what they observe as they do so, through a wide range of platforms ranging from collaborative bookmarking tools through personal and group blogs to social media sites, and thereby to find and connect with other users interested in similar topics. Such practices may not amount to journalism in an orthodox sense; they are, if anything, an example of the "random acts of journalism" which JD Lasica described as early as 2003 (LASICA, 2003a/b). But they provide a model for what may be better described as collaborative news curation by user communities: users find, share, and (often) comment on newsworthy information and events; they publicise rather than publish news stories. Performed at scale - by a sufficiently large and diverse community of dedicated participants, such collective efforts can result in forms of news coverage that are as comprehensive as those achieved by the journalism industry. The logic of such distributed, collaborative efforts is no longer one of news production, but of produsage as it also takes place in projects as diverse as Wikipedia and open source development:

\begin{abstract}
the assumption within the produsage community is that the more participants are able to examine, evaluate, and add to the contributions of their predecessors, the more likely an outcome of strong and increasing quality will be (an extension of open source's motto "given enough eyeballs, all bugs are shallow") (BRUNS, 2008a, p. 24).
\end{abstract}

At the core of both these shifts away from gatekeeping is a practice which can be usefully described as gatewatching. News users engaged in organising and curating the flood of available news stories and newsworthy information which is now available from a multitude of channels have no ability to keep - to control - the gates of any of these channels, of course; however, what they are able to do is to participate in a distributed and loosely organised effort to watch - to keep track of what information passes through these channels: what press statements are made by public actors, what reports are published by academic researchers or industry organisations, what interventions are made by lobbyists and politicians. Such gatewatching activities are far from new - journalists themselves employ similar practices when they pick 
newsworthy stories from the feeds of national and international news agencies, for example -, but by transitioning from a select few journalists with privileged access to key sources to a widespread crowdsourcing effort involving a multitude of users with diverse interests, a much broader range of topics can be addressed, and a much larger number of potentially newsworthy stories can be highlighted. While focussed only on the material contained in the MPs' expenses claims, The Guardian's own experiment at crowdsourcing journalistic investigation similarly draws on the ability of a large user base to collectively process a large body of information more quickly and effectively than a small staff of journalists, however well trained, would be able to; its journalists and editors, in turn, are engaged in a form of internal gatewatching which tracks the outcomes of this crowdsourced process of investigation to identify any particularly relevant, interesting, or outrageous findings to be explored further through more conventional journalistic activities.

The user-led, crowdsourced practices of news coverage and news curation which employ gatewatching approaches have often been described, somewhat incorrectly, as 'citizen journalism'; this is a problematic label as it appears to imply both that what participants practice here is comparable and equivalent to mainstream industrial journalism in its conventional forms, and that the professional journalists working in the industry are not also citizens (that is, invested in the future political and societal course of their country). At the same time, the mainstream journalism / citizen journalism dichotomy does neatly encapsulate a deep-set adversarial relationship between the two sides of the divide, which has dominated the 'citizen journalism' discussion for the past decade and is only now gradually being replaced by more productive attempts to explore points of connection and cooperation between 'professional' and 'citizen' journalists.

The antipathy which has dominated this relationship has historical reasons. Arguably, the breakthrough moment for citizen journalism arrived in the shape of the 1999 protests around the World Trade Organisation meeting in Seattle: anticipating a simplistic mainstream media focus on demonstrations and public unrest during the event, and a portrayal of protesters as anarchists and vandals, protest organisers set up the first Independent Media Center, or Indymedia, Website, in order to provide a platform for unedited, alternative, firsthand coverage of the protests by the protesters themselves (MEIKLE, 2002). Further Indymedia Websites in locations around the world - numbering several hundred at the height of the movement - soon 
followed. Indymedia pursued a model which was inherently antithetical to the closed gatekeeping approach of mainstream journalism: where in that model, gatekeeping is practiced at each stage of the news publication process, here gatekeeping was entirely absent - any user could contribute their own stories at the input stage; all stories were immediately progressed to the output stage; and the platform provided ample opportunity for unedited user commentary at the response stage.

While such total openness came with its own problems (several Indymedia Websites have suffered from persistent spamming and other contributions of inappropriate or undesirable material, which were duly automatically published along with more legitimate submissions), subsequent citizen journalism initiatives pursued similar models, but strengthened the collaborative curatorial aspects of their news production processes - for example by enabling their user communities to rate or vote on the quality of user-submitted content, in order to determine which submissions were ready for publication, or even by instituting collaborative 'open editing' models which enabled community members to become involved in fine-tuning story submissions from other users. Yet other sites maintained a limited degree of staff gatekeeping at the output stage - instituting a group of dedicated (but often volunteer) editors to exclude at least the most inappropriate submissions (see BRUNS, 2005, for a detailed discussion of these various models).

Common to almost all such models is also that - in keeping with the gatewatching approach, which largely focuses on the republishing, publicising, contextualisation and curation of existing material rather than the development of substantial new journalistic content - the previously atrophied response stage of the conventional news publication process became significantly more important in these alternative news sites. On many 'citizen journalism' sites, news stories themselves focus mainly on collecting, collating, curating, and contextualising a selection of news information and source materials found elsewhere on the Web - where the conventional journalistic article aims to be full-formed summary of an event or issue, the stories published on these alternative news Websites serve to open rather than close the discussion. Through the discussion process which follows (usually in discussion threads attached immediately to the story itself), further information is added, claims are evaluated, and broader context is provided - in contrast to the letters to the editor of a newspaper, for example (which are spatially and temporally removed from the original story, and often provide little more than basic endorsement or disagreement), the responses to a 
story on these sites form an integral part of the news coverage, and are perhaps even more important than the story itself.

\section{NEW DIRECTIONS FOR THE JOURNALISM INDUSTRY}

It is the centrality of this debate and discussion process which both contributed to the rise of these new forms of user-led news curation and commentary, and cemented their adversarial relationship with mainstream journalism. Again, the historical context is important here: a substantial growth in alternative Websites for the coverage and discussion of news events followed especially the events of 11 September 2001, both in the United States and in other countries. For fear of being branded unpatriotic, U.S.-based mainstream media, in particular, engaged in a considerable amount of self-censorship as they reported on the attacks and their aftermath, as well as on the belligerent response of the Bush jr. administration during the following years, leaving little space in mainstream news coverage for alternative, critical voices (SCHUDSON, 2008). Such voices were forced to pursue alternative venues, leading to the establishment of a significant number of independent Websites for the coverage and discussion of news, as well as to the emergence of other fringe forms of news coverage and discussion, such as news satire television including The Daily Show and The Colbert Report (JON ES, forthcoming 2012).

These new platforms for news commentary were often as critical of the mainstream news media as they were of the government of the day, in turn also leading to a substantial degree of retaliation from the mainstream news industry. Branding their new critics as 'armchair journalists' and political ideologues, industrial journalists have long tended to dismiss the voices representing alternative news sites outright, rather than engage with their criticism more openly and introspectively (see e.g. BRUNS, 2008b); as a result of such overly defensive responses, journalistic traditions and conventions appeared to become ever more entrenched across much of the mainstream industry. For the most part, therefore, it can be argued that the 2000s represent a lost decade for journalism innovation: not prepared to accept the validity of some of the criticism levelled at it by its new challengers, with few exceptions the industry staunchly continued on a path of business as usual that turned out to be ever more unsustainable.

Change and innovation was urgently necessary, however, not simply because of the criticisms of citizen journalists, but for far 
more fundamental, practical reasons: technological and demographic changes mean that newspaper publication, in particular, is rapidly losing its economic basis in most developed nations, as existing audiences move to online platforms and new generations grow up entirely without the experience of subscribing to, paying for, or even reading printed newspapers. Online, news business models require new approaches as well, as mainstream news Websites now compete with each other (as well as with alternative news sites, and with the news feeds of primary information sources) on a global basis, as audiences have come to expect to access their news for free and with minimal disruptions asters and public unrest, where mapping tools such as Ushahidi Maps have been deployed to provide geographical overviews of the current situation in the trouble zone by drawing on updates from official and social media sources. Here, again, journalists come to play a special role in news curation, building on the collaborative curation efforts already taking place within the social media community itself and adding to these processes their own professional expertise and industrial resources.

Such activities are by no means only the domain of professional journalists and mainstream media organisations any more, however-other organisations, and even groups of volunteers without official connections, are similarly able to operate in this space. During the January 2011 floods in southeast Queensland, for example, groups of independent developers set up a range of tools for tracking the flood crisis and provide relevant and up-to-date information at a time when the Webservers of major civic authorities were overloaded and frequently unavailable; in doing so, they provided source materials for news organisations, emergency services, and the general public alike (BRUNS, 2011). In Germany, at a time when major news organisations remained relatively uninterested in rumours that Defence Minister Karl Theodor Freiherr zu Guttenberg's PhD dissertation had been largely plagiarised from various sources, including documents compiled by the parliamentary information service, enterprising Internet users set up the GuttenPlag wiki to identify and document any instances of provable plagiarism, eventually identifying plagiarised material on nearly 95 percent of all pages and leading to the minister's resignation (GUTTENPLAG, 2011).

\section{CONCLUSION}

There is no inherent reason why journalists and journalistic organisations should not be able to play an important role as drivers of 
such initiatives, too. Professionally trained in the evaluation of stories and the curation of information, journalists have the ability to make a significant contribution to the collaborative efforts at 'working the story' that now regularly take place through social media, or even to drive these efforts both in social media spaces and through their own, dedicated platforms. To realise these possibilities, however, it is also necessary to accept what is irretrievably lost from journalism's grasp: the role of journalists as gatekeepers of information, and the positioning of news media outlets (whether in print, broadcast, or online) as the central spaces for the coverage of and engagement with the news.

Today, journalists are part of a broadening range of societal groups and actors engaging with the news; audiences, or more appropriately, news users, are increasingly able even to bypass them altogether to access first-hand information from a range of other organisations and sources. As a result, journalists must work harder to demonstrate the added value which they provide to news users through their professional investigation, curation, and commentary efforts. Additionally, in a media sphere that is abundant in both information and channels, the mainstream media no longer provide the only, or even the most important, space for the public discussion of news and current events; far from the society-wide public sphere envisaged at the height of the mass media age, the current media environment is characterized by a succession of overlapping ad hoc publics (BRUNS \& BURGESS, 2011) which form and dissolve in response to specific themes, topics, and stories. These publics exist not in any one media space or on any one media platform, but transcend and spread across these spaces, interweaving with one another as they do. News organisations may continue to control the news agenda in their own publications, but they are unlikely ever again to drive public debate throughout this complex, multifaceted media environment.

Under these circumstances, then, what remains of journalism as we knew it? Perhaps most under threat are universalist news operations other than the international market leaders: in an online environment where the news from international providers is as easy to access as that from local publishers, minor operators are unlikely to be able to compete with major companies in the depth and breadth of their coverage. Specialist news organisations - whether with a geographically local focus, or a narrow topical specialisation - may fare better in these areas, and should continue to find news users interested in their material. At an even greater level of particularity, even individual journalists with unique expertise and recognised voices 
may be able to position themselves as one-person news organisations.

But key to all of their operations, in the end, will be the development of a balance between the generation of original, valuable news content, injected into what is now a shared, distributed, decentralized newshole that exists across multiple online and social media spaces and platforms, and the curation of available materials from internal as well as external sources in ways that are unique and add enough value to attract news users. Further, none of this work takes place in isolation any more - rather, it must be done in plain sight of and preferably in cooperation and even in collaboration with news users, avoiding the aloof and sometimes patronising stance towards their audiences that journalists have so often adopted in the past. Journalism has become a mass participation activity.

NOTE

1 This paper was presented at the SBPJor Congress, Journalism and Digital Media, Rio de Janeiro, Brazil, November 3-5, 2011.

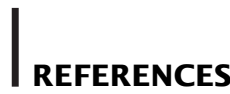

ANDERSEN, Michael. Four crowdsourcing lessons from the Guardian's (spectacular) expenses-scandal experiment. ieman Journalism Lab, Boston, 23 June 2009. Available at: <http://www.niemanlab. org/2009/06/four-crowdsourcing-lessons-from-the-guardiansspectacular-expensesscandal-experiment/>. Retrieved 29 set. 2011.

BARDOEL, Jo; DEUZE, Mark. 'Networkjournalism': Converging competencies of old and new media professionals. Australian Journalism Review, $v$. 23, n. 3, p. 91-103, dez. 2001.

BLACK, Jay (ed.). Mixed news: The public/civic/communitarian journalism debate. Mahwah, N.J.: Lawrence Erlbaum Associates, 1997.

BRUNS, Axel. Gatewatching: Collaborative online news production. New York: Peter Lang, 2005.

Blogs, Wikipedia, Second Life and beyond: From production to produsage. New York: Peter Lang, 2008a.

- The active audience: Transforming journalism from gatekeeping to gatewatching. In PATERSON, Chris; DOMINGO, David (eds.). Making online news: The ethnography of new media production. New York: 
Peter Lang, 2008b.

- Exploring the pro-am interface between production and produsage. In The Internet Turning 40: The Never-Ending Novelty of New Media Research? Conference, 17-19 June 2010, Hong Kong. Available at <http://snurb.info/files/2010/Exploring\%20the\%20ProAm\%20Interface\%20between\%20Production\%20and\%20Produsage.pdf>. Retrieved 29 set. 2011.

- Towards distributed citizen participation: Lessons from WikiLeaksand the Queensland floods. In PARYCEK, Peter; KRIPP, Manuel J.;EDELMANN, Noella (eds.). CeDEM 11 : Proceedings of the International Conference for E-Democracy and Open Government, 5-6 May 2011

Krems, Austria. Krems: Edition Donau-Universität Krems, 2011 . p. 35-52. Available at http://snurb.info/files/2011/Towards\%20Distributed\%20 Citizen\%20Participation.pdf>. Retrieved 29 set. 2011.

; BURGESS, Jean. The use of Twitter hashtags in the formation of ad hoc publics. In European Consortium for Political Communication Conference, 25-27 Aug. 2011, Reykjavík. Available at <http://snurb.info/ files/2011/ The\%20Use\%20of\%20Twitter\%20Hashtags\%20in\%20the\%20 Formation\%20 of\%20Ad\%20Hoc\%20Publics\%20(final).pdf>. Retrieved 29 set. 2011.

; HIGHFIELD, Tim. Blogs, Twitter, and breaking news: The produsage of citizen journalism. In LIND, Rebecca Ann (ed.). Producing theory: The intersection of audiences and production in a digital world. New York: Peter Lang, forthcoming 2012.

BURNS, Alex. Oblique strategies for ambient journalism. M/C journal, v. 13, n. 2, May 2010. Available at http://journal.media-culture.org.au/ index.php/mcjournal/article/view/230>. Retrieved 1 ago. 2011.

GANS, Herbert J. Deciding what's news: A study of CBS Evening News, NBC Nightly News, Newsweek, and Time. New York: Vintage, 1980.

Democracy and the news. New York: Oxford UP, 2003.

GILLMOR, Dan. Moving toward participatory journalism. Nieman reports, p. 79-80, Fall 2003.

GUTTENPLAG. 2011 . Available at <http://de.guttenplag.wikia.com/wiki/ GuttenPlag_Wiki>. Retrieved 29 set. 2011.

HERMIDA, Alfred. From TV to Twitter: How ambient news became ambient journalism. M/C journal v. 13, n. 2, May 2010. Available at <http:// journal.media-culture.org.au/index.php/mcjournal/article/view/220>. Retrieved 1 ago. 2011.

JONES, Jeffrey P. Parody, performativity, and play: The reinvigoration of citizenship through political satire. In HARTLEY, John; BURGESS, Jean; BRUNS, Axel (eds.). Blackwell companion to new media dynamics. 
London: Blackwell, forthcoming 2012.

KOVACH, Bill; ROSENSTIEL, Tom. The elements of journalism: What newspeople should know and the public should expect. New York: Crown, 2001.

LASICA, J. D. Random acts of journalism: Beyond 'is it or isn't it journalism?': How blogs and journalism need each other. JD's blog: New media musings, 12 March 2003a. Available at <http://www.jdlasica. com/blog/archives/2003_03_12.html>. Retrieved 27 set. 2004.

Blogs and journalism need each other. Nieman reports, $p 70$ 4, Fall 2003b. Available at http://www.nieman.harvard.edu/reports/033NRfall/V57N3.pdf>. Retrieved 4 jun. 2004.

LEADBEATER, Charles; MILLER, Paul. The pro-am revolution: How enthusiasts are changing our economy and society. Demos, 2004. Available at <http://www.demos.co.uk/publications/proameconomy/>. Retrieved 25 jan. 2007.

LEE, Edmund. News Corp.'s ‘Daily' trails Murdoch reader goal. Bloomberg, 29 Sep. 2011. Available at <http://www.bloomberg.com/news/201109-28/news-corp-s-daily-with-120-000-readers-trails-murdoch-goalforprofits.html>. Retrieved 29 set. 2011.

MEIKLE, Graham. Future active: Media activism and the Internet. New York: Routledge, 2002.

SCHUDSON, Michael. Why democracies need an unlovable press. Cambridge: Polity, 2008.

VICKERY, Graham; WUNSCH-VINCENT, Sacha. Participative Web and usercreated content: Web 2.0, wikis and social networking. Paris: Organisation for Economic Co-operation and Development, 2007. Available at <http:// www.sourceoecd.org/sciencelT/9789264037465>. Retrieved 9abr. 2010.

Axel Bruns is an Associate Professor in the Creative Industries Faculty at Queensland University of Technology in Brisbane, Australia, and a Chief Investigator in the ARC Centre of Excellence for Creative Industries and Innovation (http://cci.edu.au/). 